\title{
The influence of different recultivation methods on the water buffer capacity in a degraded urban lake
}

\author{
J.K. Grochowska ${ }^{(1), \star}$, R. Brzozowska ${ }^{(1)}$
}

Received October 18, 2012

Revised May 21, 2013

Accepted June 1, 2013

Key-words:

lake

recultivation, buffer capacity, alkalinity, total hardness

\section{ABSTRACT}

The object of study was Długie Lake, which is located in northeastern Poland. This lake was restored by two methods: artificial aeration and phosphorus inactivation. The aim of this study was to determine the effect of the two methods of rehabilitation on the water buffer properties of the lake. Both of the restoration methods had an impact on the lake's buffer properties. Artificial aeration reduced the production processes in the reservoir and caused the destruction of the vertical stratification of alkalinity, total hardness and calcium concentration. The phosphorus inactivation method caused a significant decrease in the concentration of phosphorus in the lake water and the further limitation of the production processes. Similar to the state before the lake aeration, a vertical stratification of alkalinity, total hardness and calcium was observed, with increasing values towards the bottom. However, the differences in the values of these parameters between surface water and bottom water were significantly lower than those recorded prior to the remediation. The observed changes after restoration of Długie Lake are very positive in that they are optimal for construction of plant cell walls, shells and fish bones.

\section{RÉSUMÉ}

L'influence de différentes méthodes de restauration sur la capacité tampon de l'eau d'un lac urbain dégradé

Mots-clés : restauration lacustre, capacité tampon, alcalinité, dureté totale
L'objet d'étude est le lac Długie qui est situé au nord de la Pologne. Ce lac a été restauré par deux méthodes : l'aération artificielle et l'inactivation du phosphore. Le but de cette étude était de déterminer l'effet des deux méthodes de réhabilitation sur les propriétés tampon de l'eau du lac. Les deux méthodes de restauration ont eu un impact sur les propriétés tampon du lac. L'aération artificielle a réduit les processus de production dans le réservoir et causé la destruction de la stratification verticale de l'alcalinité, de la dureté totale et de la concentration de calcium. Le procédé d'inactivation de phosphore a entraîné une diminution significative de la concentration de phosphore dans l'eau du lac et une limitation supplémentaire du processus de production. La stratification verticale de l'alcalinité, la dureté totale et le calcium ont été observés semblables à l'état d'avant l'aération du lac, avec des valeurs croissantes vers le fond. Cependant, les différences dans les valeurs de ces paramètres entre les eaux de surface et des eaux de fond étaient nettement inférieures à celles enregistrées avant la restauration. Les changements observés après la restauration du lac Długie sont très positifs parce que les conditions sont optimales pour la construction des parois cellulaires des plantes, des coquillages et des os de poisson.

(1) University of Warmia and Mazury in Olsztyn Faculty of Environmental Sciences, Department of Water Protection Engineering Prawocheńskiego 1, 10-720 Olsztyn, Poland

^ Corresponding author: jgroch@uwm.edu.pl 


\section{INTRODUCTION}

Excessive eutrophication of lakes is undesirable due to the manifestation of nutrient release from the sediment, and subsequently high nutrient concentrations in the water, phytoplankton blooms, decreased water transparency and bottom-water anoxia (Rast and Thornton, 1996; Ellwood et al., 2009; Zhang et al., 2010). The rapid acceleration of eutrophication related to human activities (e.g., urbanization of lake catchments, intensification of agricultural production, industrialization) has forced lake and reservoir managers to seek effective methods to reverse or inhibit this process and its disadvantageous consequences (Castillo, 2010; Friese et al., 2010). In order to improve lake water quality throughout the world, various reclamation methods (technical, biological) have been implemented which result in the permanent immobilization of nutrients in the bottom sediments or the removal of their excess outside the lacustrine ecosystem (Dunst et al., 1974; Klapper, 1991; 2003; Beutel, 2002; Cooke et al., 2005; Beutel et al. 2008; Bryant et al., 2012; Gantzer et al., 2009).

In numerous publications, it is possible to find different research results describing the effects of aeration solutions. The influence of artificial aeration on the changes in nutrient and organic compound contents, or the water transparency expressed as Secchi disc visibility were described by Kangro et al. (2005); Søndengaard et al. (2007; 2008); Özkundakci et al. (2010; 2011) and Dittrich et al. (2011). Bryant et al. (2012) discussed the influence of oxygenation on oxygen and manganese concentrations and microbial community structure. Interesting results were also obtained by Beutel (2002) and Beutel et al. (2008), who investigated the $\mathrm{Hg}$ methylation phenomenon in the anaerobic zone of lakes. Several reports exist on the influence of hypolimnetic aeration on the physico-chemical properties of water, including the components related to water buffer capacity (Ashley, 1983; Taggart and McQueen, 1981). However, there is little information in the literature about changes in the buffer capacity of artificially destratified lakes. The influence of destratification on $\mathrm{pH}$ and alkalinity in the context of decreasing blue-green algae blooms was raised by Cowell et al. (1987), but this research was carried out during a much shorter period. This raises the question: what about the other components of the water? For example, the buffer capacity of water is one of the most important variables in water quality assessment. This water property influences many biological and chemical processes in water reservoirs. In the case of measuring the effects of recultivation, it can be used for determination of the degree of water quality improvement in lakes. It is known that, due to the buffering presence of calcium carbonates, bicarbonates and "hydroxides", a lake has a fixed $\mathrm{pH}$ level, which after transient changes caused, e.g., by the input of pollutants, returns to the previous level (Hermanowicz et al., 1999). This is very important because aquatic organisms need a stable range of $\mathrm{pH}$ within an optimal range. It is very important to investigate how reclamation treatments influence the buffering properties of lake water - one of the most important limnological parameters. Because of the fact that artificial mixing causes radical changes in the chemical stratification in the lake (Cowell et al., 1987), whilst phosphorus inactivation directly influences the phosphorus level in the water column only (Cooke et al., 2005), the effect of the first method on the buffer properties of lake water is expected to be more noticeable. However, phosphorus inactivation is also able to change the environmental conditions in the lake, and it could probably have an effect on the buffer properties of lake water. The phosphorus inactivation method is simple and does not require significant financial expenditure - it has been enjoying increasing worldwide popularity recently. It is basically aimed at reducing the content of bioavailable phosphorus by its precipitation from water and durable immobilization in bottom sediments and, in consequence, a retreat of excessive eutrophication symptoms (Gawrońska et al., 2007).

Therefore, the aim of this study is to determine the effect of (1) artificial aeration with thermal destratification and (2) phosphorus inactivation on the buffer properties of the water in a stratified urban lake via the testing hypothesis that the restoration methods used cause significant differences in the mean values of $\mathrm{pH}$, carbon dioxide, alkalinity, total hardness and calcium contents among the control, experimental, and post-experimental years. 
$100,200,300 m$

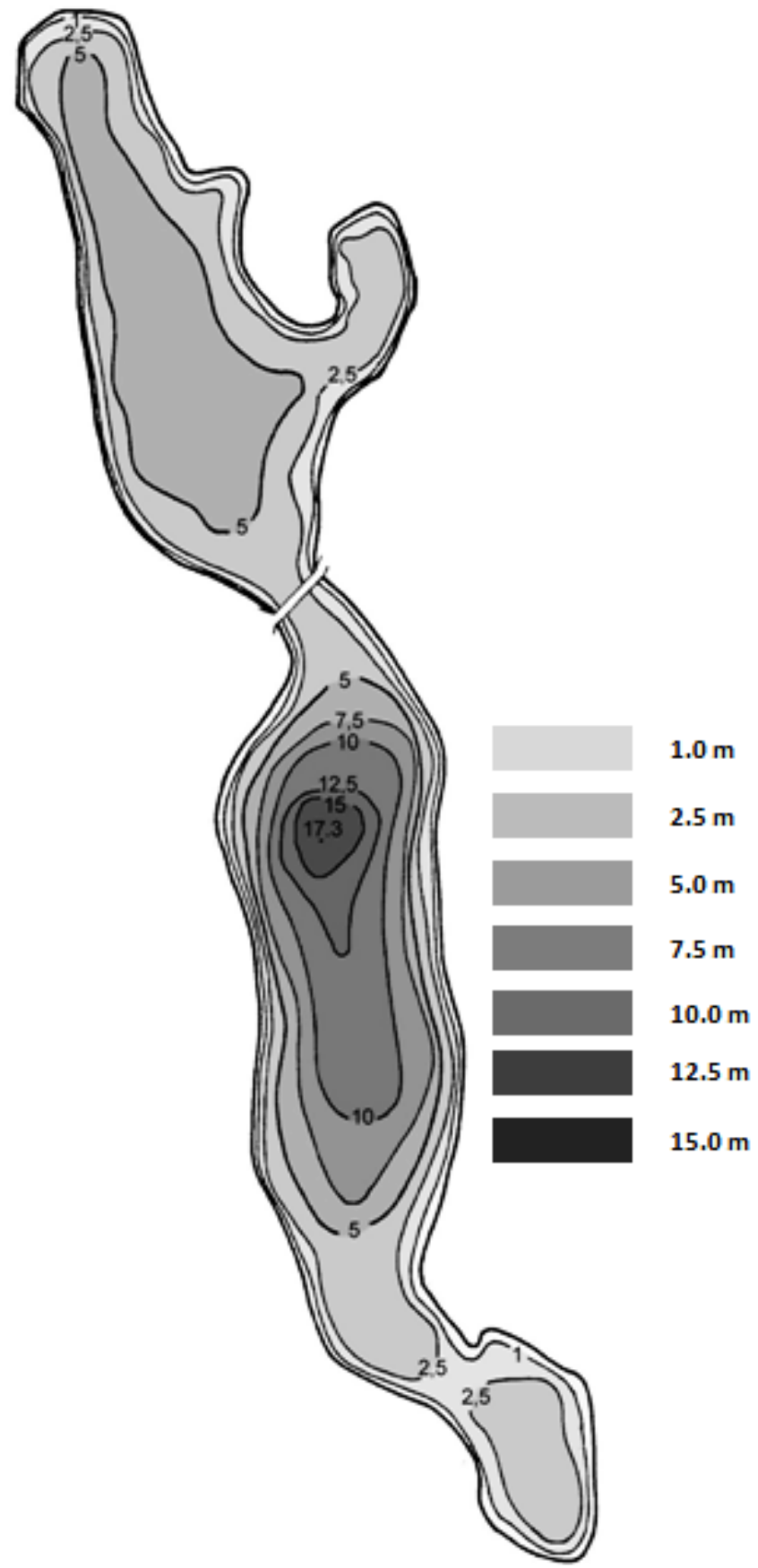

Figure 1

Bathymetric map of Długie Lake.

\section{MATERIAL AND METHODS}

The study was conducted at Długie Lake (area 26.8 ha, maximum depth $17.3 \mathrm{~m}$; Figure 1), which is located in northeastern Poland (Masurian Lake District) in Olsztyn city. The most important lake morphometric data are presented in Table I. Długie Lake has no natural surface outflows or inflows and is loaded by direct surface runoff. 
Table I

Basic morphometric data of Długie Lake.

\begin{tabular}{|l|c|}
\hline Surface area & $26.8 \mathrm{ha}$ \\
\hline Maximum depth & $17.3 \mathrm{~m}$ \\
\hline Average depth & $5.3 \mathrm{~m}$ \\
\hline Relative depth & 0.0334 \\
\hline Depth index & 0.3 \\
\hline Water volume & $1414800 \mathrm{~m}^{3}$ \\
\hline Maximum length & $1670 \mathrm{~m}$ \\
\hline Maximim width & $240 \mathrm{~m}$ \\
\hline Elongation/ $/$ & 6.9 \\
\hline Average width & $160.4 \mathrm{~m}$ \\
\hline Maximum effective length & $1225 \mathrm{~m}$ \\
\hline Maximum effective width & $325 \mathrm{~m}$ \\
\hline Length of shoreline & $4080 \mathrm{~m}$ \\
\hline Shoreline development & 2.23 \\
\hline
\end{tabular}

Długie Lake is a dimictic lake, belonging to the bradimictic subgroup, in which water mixing is difficult because of disadvantageous morphometric conditions. Under natural conditions, there is not a thorough spring circulation in the lake. A stable summer stratification period, characterized by a shallow epilimnion (2-3 m), sharp thermocline and cold hypolimnion (about $4{ }^{\circ} \mathrm{C}$ ), is quickly established. Fall circulation usually occurs late and is short-lived.

From the mid-1950s to the 1970s, Długie Lake was a storm-water and sanitary wastewater receiver, in the amount of 350 to $400 \mathrm{~m}^{3}$. day ${ }^{-1}$, for Olsztyn. During this period, inflow to the lake consisted of more than $150 \%$ of the whole lake volume (1414.8 thousand $\mathrm{m}^{3}$; Gawrońska et al., 2005). After the sewage input to the lake was discontinued, water quality was still very bad and it was necessary to apply special treatment to the lake basin.

The first method used for the Długie Lńake renovation was artificial aeration with thermal destratification. This procedure was carried out for more than 10 years - one of the longest periods in the world (Gächter and Wehrli, 1998; Grochowska and Gawrońska, 2004). The restoration of the lake via aeration was performed in two stages: during the first stage, from 1987-1990, three Miniflok aerators (Lossow 1980) were used for aeration. The aerators were located in the central, deepest part of the lake and were supported by a compressor (capacity of $150 \mathrm{~m}^{3} \cdot \mathrm{h}^{-1}$ ). In the second stage (the years 1991-1995, 1997, 1998 and 2000), two compressors (working alternately) with a capacity of $80 \mathrm{~m}^{3} \cdot \mathrm{h}^{-}$were used to support two Miniflok aerators. The main reason for changing the aeration system elements (such as the compressor type, aerator localization and the types of pipes supplying compressed air into the aerators) was the failure of the first stage to completely mix the water column (Grochowska and Gawrońska, 2004).

The other restoration method utilized in Długie Lake was phosphorus inactivation using a new generation of coagulant - PAX 18. It is polyaluminum chloride, a pre-hydrated and polymerized product, with a higher efficiency compared with conventional aluminum coagulants (Gumińska, 2011). The procedure was carried out in three stages: in spring 2001, fall 2002 and fall 2003. For each application, 20 tons of coagulant was dosed into the lake.

The laboratory analyses of selected aquatic chemical parameters (carbon dioxide, alkalinity, total hardness, calcium and $\mathrm{pH}$ measurements) were performed on samples collected in the central, deepest part of Długie Lake, at depths of $1 \mathrm{~m}$ below the surface and $16 \mathrm{~m}$ below the surface ( $1 \mathrm{~m}$ above the bottom). The study focused only on describing the changes that occurred in the center, the deepest part of the lake, because they are the most spectacular. Other parts of Długie Lake are shallow and the changes that occurred are the same as in the central portion.

Water samples were taken at one-month intervals during the period from July to November 1984 (before remediation), and from April to November 1987, 1998 and 2000 (during artificial aeration), from April to November 2001, 2002 and 2003 (during phosphorus inactivation), and from April to November 2011 (the control year). The carbon dioxide content was 


\section{Table II}

Results of one - way ANOVA analyses (with Tukey HSD) for investigated variables in Długie Lake water.

\begin{tabular}{|l|c|c|c|}
\hline Variable & $F$ value & $p$ value & $\begin{array}{c}\text { Years which different significantly } \\
\text { from 1984 (before recultivation) }\end{array}$ \\
\hline pH surface water & 0.171 & 0.990 & - \\
pH near-bottom water & 15.72 & 0.000 & $1998,2000,2001,2002,2011$ \\
\hline $\mathbf{C O}_{2}$ surface water & 1.61 & 0.153 & - \\
$\mathbf{C O}_{2}$ near-bottom water & 18.09 & 0.000 & $1998,2000,2001,2002,2003,2011$ \\
\hline Alkalinity surface water & 12.98 & 0.000 & $1999,2000,2011$ \\
Alkalinity near-bottom water & 31.72 & 0.000 & $1987,1998,2000,2001,2002,2003,2011$ \\
\hline Total hardness surface water & 16.53 & 0.000 & $1998,2000,2002,2003,2011$ \\
Total hardness near-bottom water & 8.66 & 0.000 & $1987,1998,2000,2002,2003,2011$ \\
\hline Calcium surface water & 27.35 & 0.000 & $1998,2000,2001,2002,2003,2011$ \\
\hline Calcium near-bottom water & 11.75 & 0.000 & $1987,1998,2000,2002,2003,2011$ \\
\hline
\end{tabular}

measured by the titration method using $\mathrm{Na}_{2} \mathrm{CO}_{3}$ and phenolphthalein as an indicator. Calcium, total hardness and alkalinity were measured by the titration method - calcium and total hardness with EDTA; alkalinity with $\mathrm{HCl}$ solution and methyl orange indicator. All analyses were performed in triplicate. Chemical analyses of water were performed in accordance with Standard Methods (1980) and Hermanowicz et al. (1999).

The results obtained were statistically analyzed (one-way ANOVA, $p=0.05$, Tukey's HSD) using the Statistica 9.0 software package (StatSoft Inc., 2010). The alternatively tested hypothesis was the presence of significant differences in mean values of $\mathrm{pH}$, carbon dioxide, alkalinity, total hardness and calcium contents among the control year (1984), the experimental years (1987, 1998, 2000 - artificial aeration; 2001-2003 - phosphorus inactivation) and a post-experimental year (2011).

\section{RESULTS}

The statistical analysis of the results obtained showed that the rehabilitation methods used did not cause significant changes in $\mathrm{pH}$ and carbon dioxide concentrations in the surface water of Długie Lake Table II). In all research years (before remediation, during artificial aeration, during phosphorus inactivation and in the post-experimental year), the $\mathrm{pH}$ of surface water layers varied in the range from 7.3 to 8.9 , and its average value fluctuated around $\mathrm{pH} 8.3$ (Figure 2). These changes were not statistically significant. The distribution of $\mathrm{CO}_{2}$ concentrations in the upper water layers changed within the range from 0.0 to $17.5 \mathrm{mg} \cdot \mathrm{CO}_{2} \cdot \mathrm{L}^{-1}$, and average annual amounts ranged from 1.1 to $6.7 \mathrm{mg} \cdot \mathrm{CO}_{2} \cdot \mathrm{L}^{-1}$ (Figure 3 ).

The statistical analysis showed highly significant differences in the values of these parameters in the bottom water (Table II). Before rehabilitation, the $\mathrm{pH}$ of the bottom water was quite low, with a pH of 6.9 on average, and the average amount of $\mathrm{CO}_{2}$ reached $75.3 \mathrm{mg} \cdot \mathrm{L}^{-1}$ (Figure 2). In 1987 , when the artificial aeration began, a slight decrease in both $\mathrm{pH}$ and $\mathrm{CO}_{2}$ concentration was observed - the average values of these parameters were $\mathrm{pH} 6.8$ and $66.7 \mathrm{mg} \cdot \mathrm{CO}_{2} \cdot \mathrm{L}^{-1}$. In the subsequent years of aeration, the changes were noticeable. The $\mathrm{pH}$ increased to 7.8 on average in 1998 and to 7.7 in the last aeration year, and carbon dioxide concentrations decreased to $7.8 \mathrm{mg} \cdot \mathrm{CO}_{2} \cdot \mathrm{L}^{-1}$ (in 1998) and $9.7 \mathrm{mg} \cdot \mathrm{CO}_{2} \cdot \mathrm{L}^{-1}$ (in 2000) (Figure 3). During the application of the phosphorus inactivation method a small decrease in the average $\mathrm{pH}$ value to 7.2 (in 2003) and $7.4(2001,2002)$, and an increase in carbon dioxide concentrations (from $23.5 \mathrm{mg} \cdot \mathrm{L}^{-1}$ in 2001 to $29.7 \mathrm{mg} \cdot \mathrm{L}^{-1}$ in 2003) were observed. In the last control year (2011), the average $\mathrm{pH}$ was 7.4 and average $\mathrm{CO}_{2}$ concentration was $27.9 \mathrm{mg} \cdot \mathrm{L}^{-1}$ (Figures 2, 3).

In the case of the other parameters considered (alkalinity, total hardness and calcium concentration), the statistical analysis showed that both applied restoration methods significantly influenced the values of these parameters in the whole water volume of Długie Lake (Table II). Prior to remediation, the vertical stratification of alkalinity and total hardness was characterized by increasing values toward the bottom. The average value of alkalinity in the surface 
J.K. Grochowska and R. Brzozowska: Knowl. Managt. Aquatic Ecosyst. (2013) 410, 01

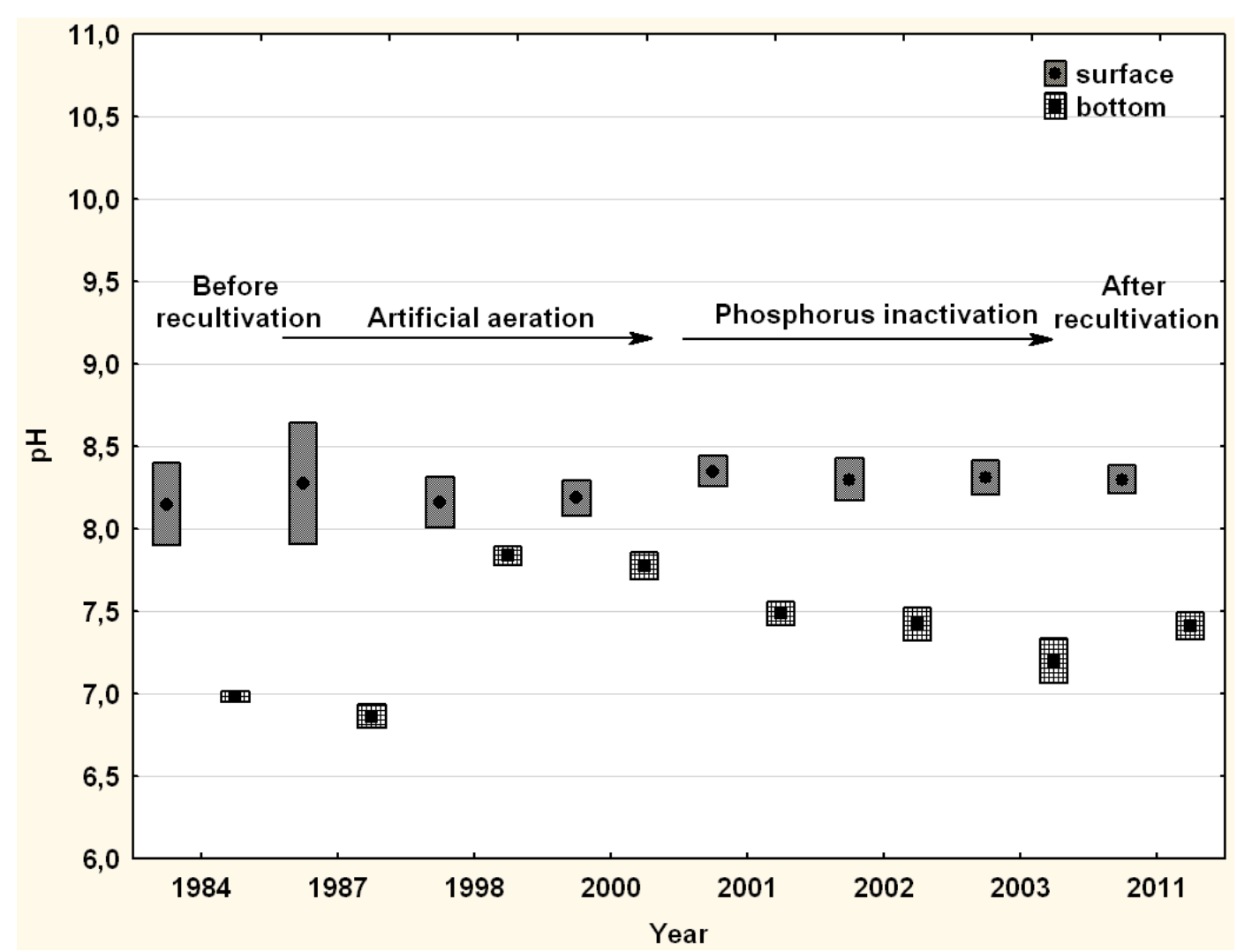

Figure 2

Mean annual values of $\mathrm{pH}(+/-S E M$ and SD) in the water of Długie Lake.

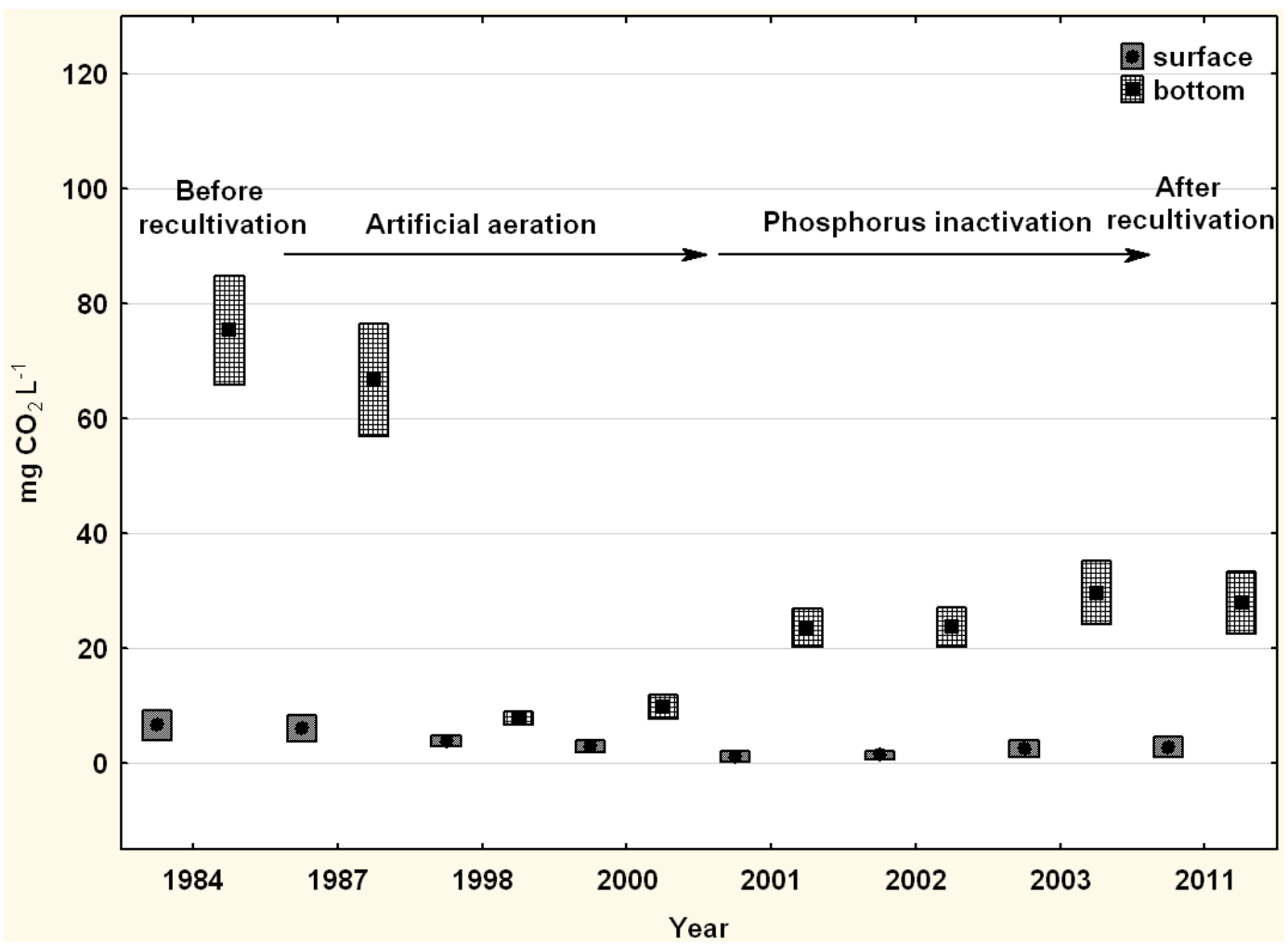

Figure 3

Mean annual values of $\mathrm{CO}_{2}$ content (+/- SEM and SD) in the water of Długie Lake. 


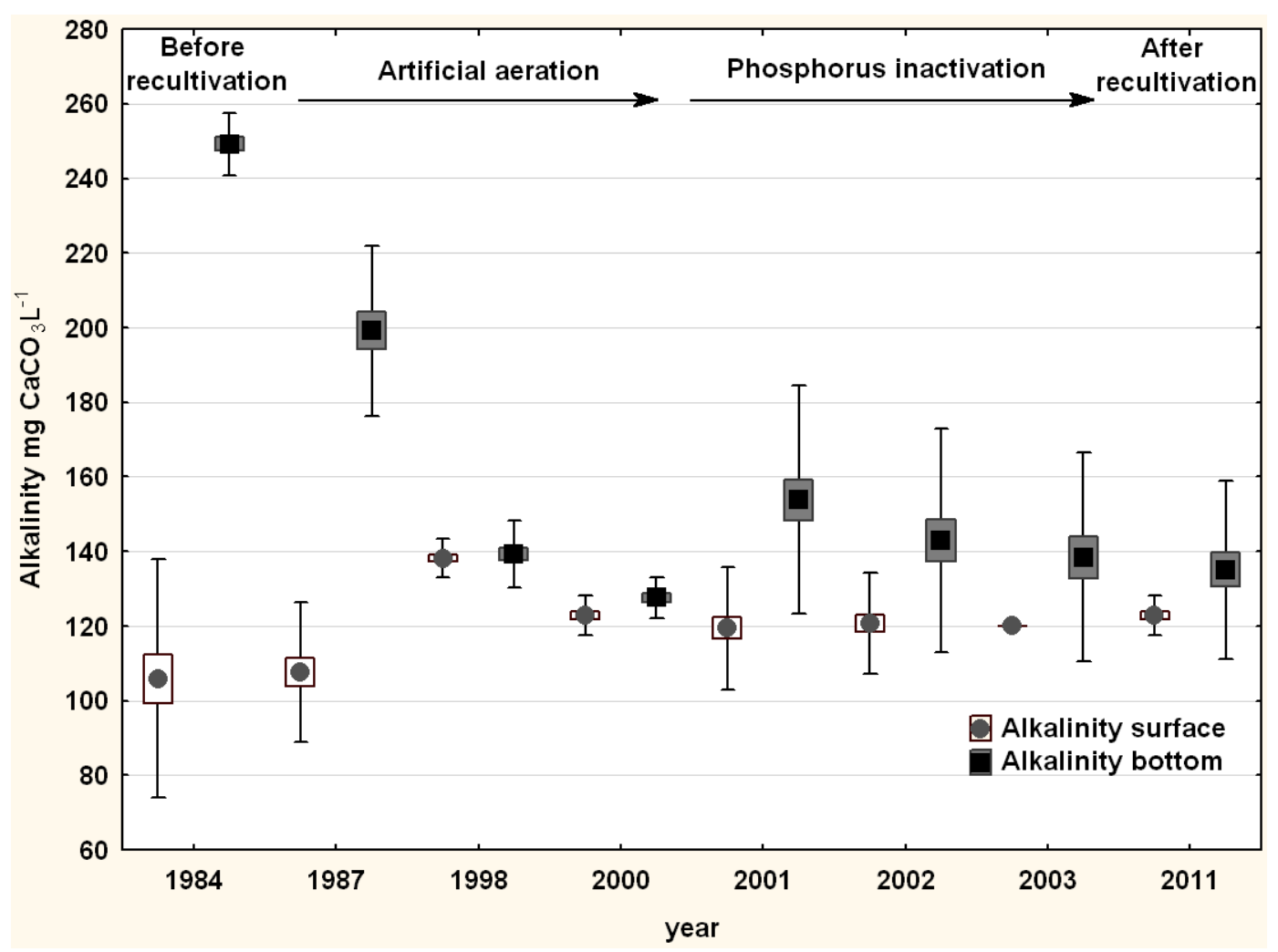

Figure 4

Mean annual values of alkalinity (+/- SEM and SD) in the water of Długie Lake.

water layer was then $105.1 \mathrm{mg} \cdot \mathrm{CaCO}_{3} \cdot \mathrm{L}-1$ and the hardness was $100.1 \mathrm{mg} \cdot \mathrm{CaCO}_{3} \cdot \mathrm{L}^{-1}$. The average alkalinity in the bottom water was $240.2 \mathrm{mg} \cdot \mathrm{CaCO}_{3} \cdot \mathrm{L}^{-1}$ and total hardness was $170.1 \mathrm{mg} \cdot \mathrm{CaCO}_{3} \cdot \mathrm{L}^{-1}$ (Figures 4, 5). After beginning aeration (1987), both investigated parameters were reduced throughout the water column, although differences between the surface (alkalinity $100.1 \mathrm{mg} \cdot \mathrm{CaCO}_{3} \cdot \mathrm{L}^{-1}$, total hardness $95.1 \mathrm{mg} \cdot \mathrm{CaCO}_{3} \cdot \mathrm{L}^{-1}$ ) and bottom water (alkalinity $180.1 \mathrm{mg} \cdot \mathrm{CaCO}_{3} \cdot \mathrm{L}^{-1}$, total hardness $140.1 \mathrm{mg} \cdot \mathrm{CaCO}_{3} \cdot \mathrm{L}^{-1}$ ) were still visible (Figures 4,5 ). In the subsequent years of aeration, the alkalinity and hardness levels increased and were similar throughout the entire lake water volume (in 1998 the average alkalinity amounted to $140.1 \mathrm{mg} \cdot \mathrm{CaCO}_{3} \cdot \mathrm{L}^{-1}$ and total hardness was $145.1 \mathrm{mg} \cdot \mathrm{CaCO}_{3} \cdot \mathrm{L}^{-1}$, in 2000 the values of both parameters were $125.1 \mathrm{mg} \cdot \mathrm{CaCO}_{3} \cdot \mathrm{L}^{-1}$ ). As a result of coagulant application in the years 2001-2003, a difference in the values of alkalinity and total hardness between the surface and bottom water was created. Simultaneously, the alkalinity and total hardness of the surface water layer decreased (to about $120.1 \mathrm{mg} \cdot \mathrm{CaCO}_{3} \cdot \mathrm{L}^{-1}$ ) while these parameters increased, relative to during aeration, in the bottom water (Figures 4, 5). A similar situation was maintained in 2011, when the alkalinity and total hardness of the surface water reached an average of $120.1 \mathrm{mg} \cdot \mathrm{CaCO}_{3} \cdot \mathrm{L}^{-1}$ and $130.1 \mathrm{mg} \cdot \mathrm{CaCO}_{3} \cdot \mathrm{L}^{-1}$, respectively. In the bottom water, alkalinity and hardness reached levels of $135.1 \mathrm{mg} \cdot \mathrm{CaCO}_{3} \cdot \mathrm{L}^{-1}$ and $140.1 \mathrm{mg} \cdot \mathrm{CaCO}_{3} \cdot \mathrm{L}^{-1}$ on average, respectively (Figures 4,5 ).

Prior to remediation, a high level of calcium was observed in the water of Długie Lake, with distinct vertical stratification and increasing values towards the bottom $\left(29.2 \mathrm{mg} \cdot \mathrm{Ca} \cdot \mathrm{L}^{-1}\right.$ at the surface, $51.4 \cdot \mathrm{mg} \cdot \mathrm{Ca} \cdot \mathrm{L}^{-1}$ at the bottom on average) (Figure 6). During the first year of artificial aeration a slight decrease in $\mathrm{Ca}$ concentrations throughout the water volume was noted, but significant differences were still observed in the water column (Figure 6). Before the restoration these parameters were very high in the bottom waters. When the water was mixed there was an increase in parameter values at the surface, because they were drawn from the lower parts of the lake. 
J.K. Grochowska and R. Brzozowska: Knowl. Managt. Aquatic Ecosyst. (2013) 410, 01

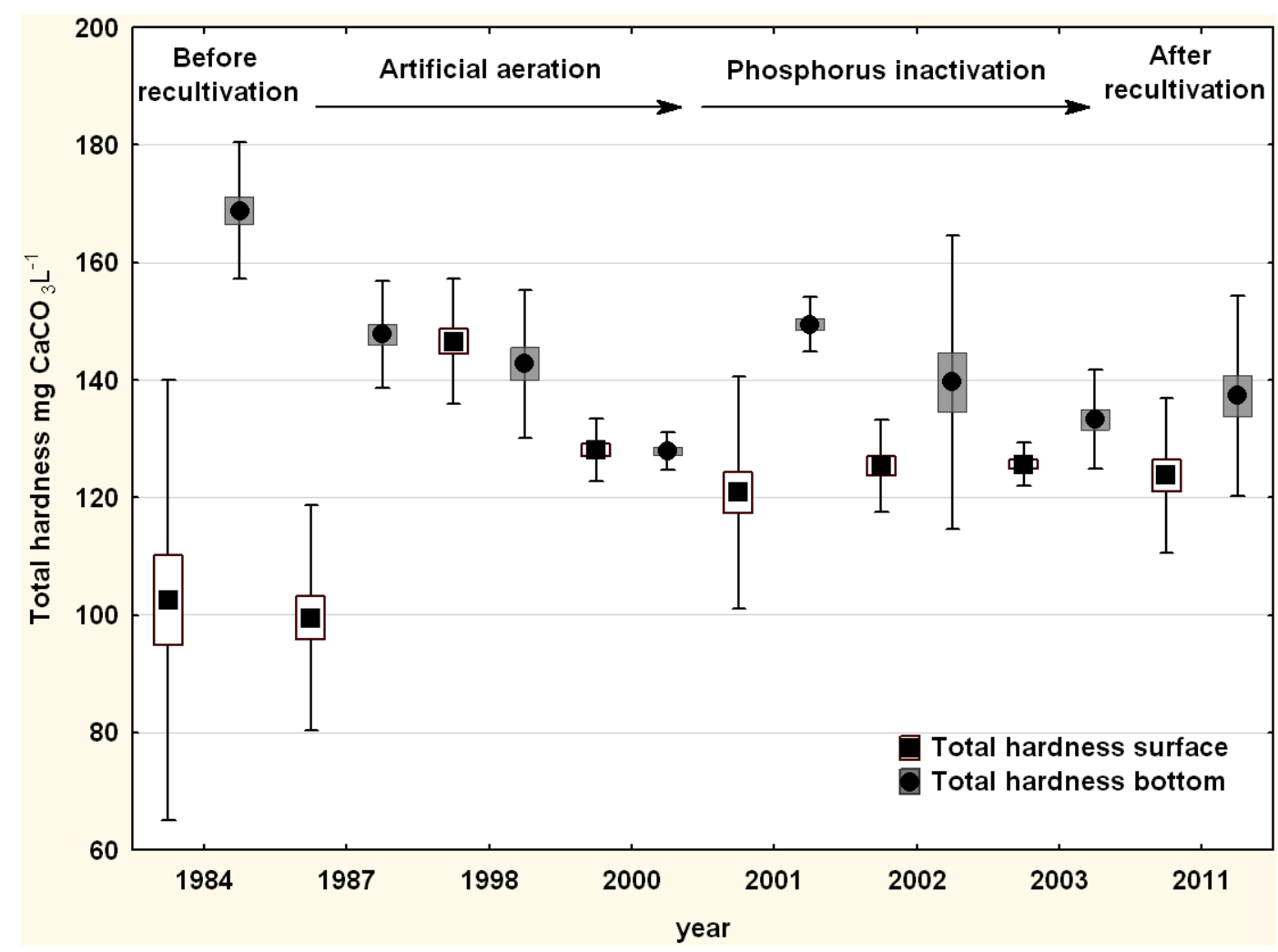

Figure 5

Mean annual values of total hardness (+/- SEM and SD) in the water of Długie Lake.

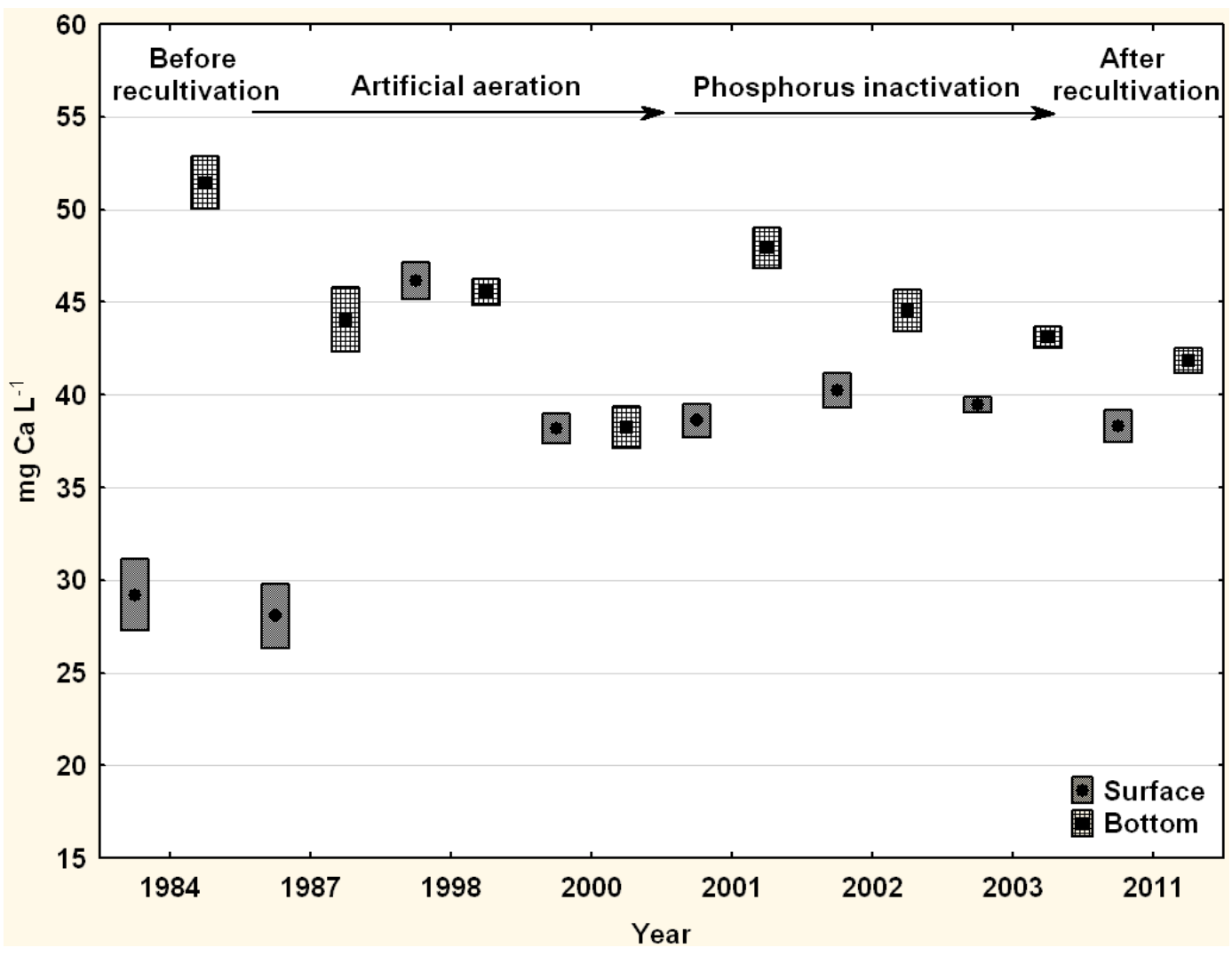

Figure 6

Mean annual values of calcium content (+/- SEM and SD) in the water of Długie Lake. 
In the subsequent years of artificial aeration the Ca concentration oscillated widely. In 1998, the average annual amount of calcium amounted to $46 \mathrm{mg} \cdot \mathrm{Ca} \cdot \mathrm{L}^{-1}$, while in 2000 , Ca levels were $38 \mathrm{mg} \cdot \mathrm{L}^{-1}$ on average (Figure 6). It is worth noting that the $\mathrm{Ca}$ amounts were similar at the surface and in the bottom zone during artificial mixing after the initial year of aerator operation.

The halt of the artificial aeration resulted in a return to the pre-aeration situation. During the application of the phosphorus inactivation method, in the deepest part of the lake oxygen depletion was observed in the near-bottom zone. A clear difference in concentrations between the surface and bottom water layers was observed again. The average annual concentration of calcium in the superficial water layer oscillated around $39 \mathrm{mg} \cdot \mathrm{Ca} \cdot \mathrm{L}^{-1}$, and in the over-bottom water layer ranged from 43 to $47 \mathrm{mg} \cdot \mathrm{Ca} \cdot \mathrm{L}^{-1}$ (Figure 6 ). In the post-experimental control year (2011), the situation was similar (Figure 6).

\section{DISCUSSION}

The raw wastewater which was loaded into Długie Lake caused total degradation, defined as saprotrophy. This was reflected in the surface water oxygen oversaturation reaching $290 \%$, while the water below 5-m depth, and in extreme cases less than $2 \mathrm{~m}$, were deoxygenated. At that time, total nitrogen concentrations increased to $30 \mathrm{mg} \cdot \mathrm{N} \cdot \mathrm{L}^{-1}$ and total phosphorus exceeded the level of $12 \mathrm{mg} \cdot \mathrm{P} \cdot \mathrm{L}^{-1}$. Massive phytoplankton growth was also observed in Długie Lake, which was manifested by extremely high chlorophyll a concentrations, average value $200 \mu \mathrm{g} \cdot \mathrm{L}^{-1}$ (maximum value $500 \mu \mathrm{g} \cdot \mathrm{L}^{-1}$ ), paired with simultaneously very poor species composition with a clear dominance of cyanobacteria and green algae (Mucha and Rybak, 1979; Rodziewicz and Rybak, 1979).

The wastewater load cut-off resulted in a mere transition from saprotrophic to hypertrophic conditions in Długie Lake (Gawrońska, 1984). These observed changes were further confirmed by Cullen and Forsberg (1988), who assessed the irreversible consequences of lake degradation.

In 1984, nutrient concentrations were still very high and favored phytoplankton blooms. In the surface water the intensive processes of primary production were accompanied by high $\mathrm{pH}$, reaching 8.9, and lack of free carbon dioxide. Such a phenomenon was observed in other lakes (Stabel, 1986; Zagan and Enache, 2009). In the over-bottom water, where the reducing conditions prevailed for most of the year, the anaerobic decomposition processes of organic matter took place. The $\mathrm{pH}$ of these waters did not exceed a value of $\mathrm{pH} 7$, with $\mathrm{CO}_{2}$ concentrations reaching up to $112 \mathrm{mg} \cdot \mathrm{L}^{-1}$. In the period prior to the rehabilitation the parameters determining the buffer properties of the water showed a strong vertical stratification, with increasing values towards the bottom. At the same time, their values were high (alkalinity $255.2 \mathrm{mg} \cdot \mathrm{CaCO}_{3} \cdot \mathrm{L}^{-1}$, total hardness $-170.1 \mathrm{mg} \cdot \mathrm{CaCO}_{3} \cdot \mathrm{L}-1$, calcium $-54.3 \mathrm{mg} \cdot \mathrm{Ca} \cdot \mathrm{L}^{-1}$ ), which was evidence of a good water buffer capacity and allowed the classification of Długie Lake as hard water type. The sharp vertical stratification of alkalinity, total hardness and calcium is also a reflection of increasing production processes. According to Kusakabe et al. (2000), during photosynthesis the depletion of free carbon dioxide and shifting of chemical equilibrium between the forms of calcium carbonates which are present in the water occur. As a result, the precipitated calcite precipitates towards the hypolimnion water which is rich in carbon dioxide and under its influence calcite is dissolved, causing an increase in the Ca concentration in the over-bottom water (around $20 \mathrm{mg} \cdot \mathrm{Ca} \cdot \mathrm{L}^{-1}$ ). The more intensive the production processes, the clearer the difference in the alkalinity and calcium content between the surface and bottom. The beginning of the artificial aeration with thermal destratification caused distinct changes in the thermal and chemical arrangements in the lake and the reduction of its trophic status. The statistical analysis showed that during the aeration there were significant changes in $\mathrm{pH}$ and carbon dioxide concentrations in the lake over-bottom water layer. According to Gawrońska and Lossow (2003) and Grochowska and Gawrońska (2004), the supply of the over-bottom water layer with compressed air allowed continuous mixing of the lake water, which resulted in oxygenation of the over-bottom water layer, and oxygen concentrations did not decrease 
below the level of $2 \mathrm{mg} \cdot \mathrm{O}_{2} \cdot \mathrm{L}^{-1}$. Simultaneously, the water temperature during the growing season was much higher than in the natural conditions. The created conditions were conducive to the organic matter mineralization processes, and carbon dioxide derived from the decomposition of organic compounds was distributed throughout the whole lake water volume. In recent years of aeration the amounts of carbon dioxide near the lake bottom did not exceed $20 \mathrm{mg} \cdot \mathrm{CO}_{2} \cdot \mathrm{L}^{-1}$, and the $\mathrm{pH}$ did not decrease below $\mathrm{pH}$ 7.6. The reduction of the lake trophic status which was associated with a decrease in nitrogen and phosphorus concentration, and the constant water mixing resulted in a reduction of the production processes in the reservoir. This was reflected in the destruction of the vertical stratification of alkalinity, total hardness and calcium concentration. At the same time, the condition changes in the over-bottom water $-\mathrm{pH}$ and redox potential increase in the water-sediment interface - caused settled calcium compounds from the upper water layer to change and be bound permanently in the sediment. This was confirmed by Koschel et al. (1983), who stated that calcium is precipitated into the sediment in the form of calcite only at high $\mathrm{pH}$. As a result of the applied restoration method the calcium content decreased in the whole lake. The precipitation of the excess calcium from the water increased its quantity in the sediments (Gawrońska et al., 2003; Brzozowska and Gawrońska, 2005).

The next restoration method of Długie Lake was based on the precipitation of the phosphorus excess from the water column and its persistent blocking in the bottom sediments. Phosphorus inactivation had decreased the nutrient concentrations in the range of values characteristic for lakes with a low trophy level (Gawrońska and Brzozowska, 2002; Gawrońska et al., 2002). This method does not directly affect the thermal and oxygen arrangements in the lake, and because of that the natural thermal stratification (with division into epilimnion, metalimnion and hypolimnion) was noted at the time of phosphorus inactivation as well as after the end of this treatment in Długie Lake. Hypolimnion water was deoxygenated, but the range of the anaerobic layer decreased and the duration of reducing conditions was shortened. The radical decrease in the phosphorus concentration in the investigated lake water resulted in further reduction in the production processes, but in the superficial water layer $\mathrm{pH}$

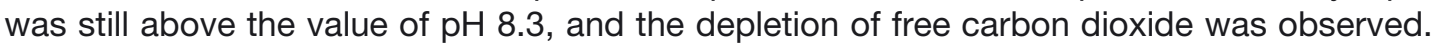
In the over-bottom water layers of the lake carbon dioxide was observed continuously, but its concentration did not exceed $50 \mathrm{mg} \cdot \mathrm{CO}_{2} \cdot \mathrm{L}^{-1}$, despite anoxic conditions. During 2001-2003 and in the control year of 2011, it was recorded that, as prior to the lake aeration period, the vertical stratification of alkalinity, total hardness and calcium was observed, with increasing values towards the bottom. The sharp vertical stratification of alkalinity, total hardness and calcium is a reflection of increasing production processes. During the artificial aeration and the phosphorus inactivation the reduction of primary production (photosynthesis processes) was achieved as an effect of improvement of the water quality in the lake. The effect of this was the increase in carbon dioxide concentrations and decrease in $\mathrm{pH}$ in the surface water layer. During photosynthesis the depletion of free carbon dioxide and shifting of the chemical equilibrium between the forms of calcium carbonates which are present in the water occur. As a result, the calcite is precipitated towards the hypolimnion water which is rich in carbon dioxide, and under its influence the calcite is dissolved, causing an increase in the Ca concentration in the over-bottom water. The more intensive production processes cause a clearer difference in the alkalinity and calcium content between the surface and bottom. Studies conducted in the lake during control years (1999 - without aeration) showed that the lake returned to its natural thermal and chemical stratification. However, the values of the observed parameters were higher at the surface and lower near the bottom. This was due to reduction of the primary production processes in the lake. Comparing the changes in concentration of the investigated parameters in the last year without aeration (Grochowska and Gawrońska, unpublished data) with the data obtained during and after phosphorus inactivation allows one to make the supposition that they could be caused by inactivation.

It is worth noting that the differences in these parameter values between the surface water and over-bottom water were much lower than those recorded before the remediation. This situation seems to confirm the durability of changes caused by application of both restoration 
methods. The values of the parameters defining the lake water buffer properties in years when inactivation of phosphorus was carried out, and in 2011, allow the classification of the Długie Lake water as medium-hard according to the classification proposed by Dojlido (1995).

The changes obtained are very positive because water that is too hard is not conducive to the development of aquatic organisms, whilst the values obtained in Długie Lake after restoration are optimal for construction of plant cell walls, shells and fish bones. The confirmation of this was an increase in the biodiversity of the littoral macrophytes (Myriophylletum spicati, Ranunculatum circinati, Ceratophylletum demersi) which was recorded by Ciecierska (2006) and favorable changes in trichopterofauna, consisting of the increasing number of species and the appearance of rare and endangered species (Agrypnia picta, Ylodes simulans) (Pietrzak and Czachorowski, 2004).

Analysis of the test results obtained over the years shows that both methods of lake recovery caused significant changes in the water buffer properties in Długie Lake. These changes were due to processes taking place inside the lake only, because the size of the catchment (the Ohle index, the ratio of catchment area to lake surface area, is 5.1), its development and impact on the reservoir did not change throughout the years of research.

\section{ACKNOWLEDGEMENTS}

The authors would like to thank Prof. Helena Gawrońska for scientific consultations and Marzena Karpienia, MSc, for carrying out the laboratory analyses.

\section{REFERENCES}

Ashley K.I., 1983. Hypolimnetic aeration of a naturally eutrophic lake: Physical and chemical effects. Cana. J. Fish. Aquatic Sci., 40, 1343-1359.

Beutel M., 2002. Improving raw water quality with hypolimnetic oxygenation. AWWA 2002 Annual Conference, Brown and Caldwell Environmental Engineering and Consulting, 2-16.

Beutel M.W., Leonard T.M., Dent S.R. and Moore B.C., 2008. Effects of aerobic and anaerobic conditions on $\mathrm{P}, \mathrm{N}, \mathrm{Fe}, \mathrm{Mn}$ and $\mathrm{Hg}$ accumulation in waters overlaying profundal sediments of an oligo-mesotrophic lake. Water Res., 42, 1953-1962.

Bryant L.D., Little J.C. and Bürgmann H., 2012. Response of sediment microbial community structure in a freshwater reservoir to manipulations in oxygen availability. Microbiol. Ecol., 80, 248-263.

Brzozowska R. and Gawrońska H., 2005. Influence of a multi - year artificial aeration of a lake using destratification method on the sediment - water phosphorus exchange. Archive of Environmental Protection, 31, 71-88.

Castillo M.M., 2010. Land use and topography as predictors of nutrient levels in a tropical catchment. Limnologica, 40, 322-329.

Ciecierska H., 2006. Changes in the littoral vegetation of Lake Długie in Olsztyn caused by restoration. Mat. Conf. on "The Functioning of Water Ecosystems and Their Protection", $53 \mathrm{p}$.

Cooke G.D., Welch E.B., Peterson S.A. and Newroth P.R., 2005. Restoration and management of lakes and reservoirs. Taylor \& Francis, A CRC Press, Boca Raton, Florida, $591 \mathrm{p}$.

Cowell B.C., Dawes C.J., Gardiner W.E. and Scheda S.M., 1987. The influence of whole lake aeration on the limnology of a hypereutrophic lake in central Florida. Hydrobiologia, 148, 3-24.

Cullen P. and Forsberg C., 1988. Experiences with reducing point sources of phosphorus to lakes. Hydrobiology, 170, 321-336.

Dittrich M., Gabriel O., Rutzen C. and Koschel R., 2011. Lake restoration by hypolimnetic $\mathrm{Ca}(\mathrm{OH})_{2}$ treatment: impact on phosphorus sedimentation and release from sediment. Science of the Total Environment, 409, 1504-1515.

Dojlido J.R., 1995. Chemia wód powierzchniowych. Wyd. Ekonomia i Środowisko, Białystok, 342 p.

Dunst R.C., Born S.M., Uttomark P.D., Smith S.A., Nichols S.A., Peterson J.O., Knauer D.R., Serns S.L., Winter D.R. and Wirth T.L., 1974. Survey of lake rehabilitation techniques and experiences. Department of Natural Resources, Madison Tech. Bull., 75, 177 p. 
Ellwood N.T. W., Albertano G.R., Funiciello R. and Mosello R., 2009. Water chemistry and trophic evaluation of Lake Albano (Central Italy): a four year water monitoring study. Journal of Limnology, 68, 288-303.

Friese K., Schmidt G., Carcalho de Lena J., Nalini Jr H.A. and Zachmann D.W., 2010. Anthropogenic influence on the degradation of an urban lake - The Pampulha reservoir in Belo Horizonte, Minas Gerais, Brazil. Limnologica, 40, 114-125.

Gächter R. and Wehrli B., 1998. Ten years of artificial mixing and oxygenation. No effect on the internal phosphorus loading of two eutrophic lakes. Environmental Science and Technology, 32, 3659-3665.

Gantzer P.A., Bryant L.D., Little J.C., 2009. Effect of hypolimnetic oxygenation on oxygen depletion rates in two water-supply reservoirs. Water Res., 43, 1700-1710.

Gawrońska H. and Brzozowska R., 2002. Influence of the PAX coagulant application on internal loading in Lake Długie. Limnological Review, 2, 111-119.

Gawrońska H. and Lossow K., 2003. Possibilities of saprotrophic lake recultivation examplified by Lake Długie in Olsztyn. Polish Journal of Environmental Studies, 12, 301-307.

Gawrońska H., Brzozowska R., Grochowska J. and Lossow K. 2003. Possibilities to reduce internal loading to lake water by artificial aeration. Polish Journal of Environmental Studies, 12, 171-179.

Gawrońska H., Lossow K. and Grochowska J., 2002. Influence of aluminium coagulant PAX on the aquatic environment of Lake Długie in Olsztyn. Limnological Review, 2, 121-130.

Gawrońska H., Lossow K. and Grochowska J. 2005. Rekultywacja Jeziora Długiego w Olsztynie. Wydawnictwo Edycja, Olsztyn, 52 p.

Gawrońska H., Łopata M. and Jaworska B. 2007. The effectiveness of the phosphorus inactivation method in reducing the trophy of lakes of different morphometric and hydrological features. Limnological Review, 7, 23-34.

Grochowska J. and Gawrońska H., 2004. Restoration effectiveness of a degraded lake using multi year artificial aeration. Polish Journal of Environmental Studies, 13, 671-681.

Gumińska J., 2011. Wpływ transformacji form glinu na skuteczność oczyszczania wody z zastosowaniem koagulantów spolimeryzowanych. Ochrona Środowiska, 33,17-21.

Hermanowicz W., Dożańska W., Dojlido J., Koziorowski B. and Zerbe J. 1999. Fizyczno - chemiczne badanie wody i ścieków. Arkady, Warszawa, 530 p.

Kangro K., Langaste R., Nõges P. and Ott I., 2005. Long - term changes and seasonal development of phytoplankton in a strongly stratified, hypertrophic lake. Development in Hydrobiology, 182, 91-103.

Klapper H., 1991. Control of eutrophication in inland waters. Ellis Horwood, New York, 337 p.

Klapper H., 2003. Technologies for lake restoration. Journal of Limnology, 62, 73-90.

Koschel R., Benndorf J., Proft G. and Recknagel F., 1983. Calcite precipitation as a natural control mechanism of eutrophication. Archive of Hydrobiology, 98, 380-408.

Kusakabe M., Tanyileke G.Z., McCord S.A. and Schladow S.G., 2000. Recent pH and $\mathrm{CO}_{2}$ profiles at Lakes Nyos and Monoun, Cameroon: implications for the degassing strategy and its numerical simulation. Journal of Volcanology and Geothermal Research, 97, 241-260.

Lossow K., 1980. Wpływ sztucznej destratyfikacji na układy fizyko - chemiczne Jeziora Starodworskiego. Zeszyty Naukowe ART w Olsztynie, 11, 3-64.

Mucha A. and Rybak M., 1979. Zawartość chlorofilu w fitoplanktonie Jeziora Długiego. Zeszyty Naukowe ART Olsztyn, 9, 47-3.

Özkundakci D., Duggan I.C. and Hamilton D.P., 2011. Lake restoration: Does sediment capping have past - application effects on zooplankton and phytoplankton? Hydrobiology, 661, 55-64.

Özkundakci D., Hamilton D.P. and Scholes P., 2010. Effect of intensive catchment and in - lake restoration procedures on phosphorus concentrations in a eutrophic lake. Ecological Engineering, 36, 396-405.

Pietrzak L. and Czachorowski S., 2004. Jak rekultywacja wpływa na owady wodne? Przykład chruścików (Trichoptera) z Jeziora Długiego w Olsztynie. Mat. V Konf. Naukowo - Technicznej nt. “Ochrona i rekultywacja jezio", Grudziądz 2004, 187-194.

Rast W. and Thornton J.A., 1996. Trends in eutrophication research and control. Hydrological Processes, 10, 295-313. 
Rodziewicz H. and Rybak M., 1979. Plankton roślinny Jeziora Długiego. Zeszyty Naukowe ART Olsztyn, 9, 55-62.

Søndergaard M., Jeppensen E., Lauridsen T.L., Skov Ch., Van Nes E.H., Roijackers R., Lammens E. and Portielje R., 2007. Lake restoration: successes, failures and long - term effects. J. Appl. Ecol., 44, 1095-1105.

Søndergaard M., Liboriussen L., Pedersen A.R. and Jeppensen E., 2008. Lake restoration by fish removal: Short - and Long - term effects in 36 Danish Lakes. Ecosystems, 11, 1291-1305.

Stabel H., 1986. Calcite precipitation in Lake Constance: Chemical equilibrium, sedimentation, and nucleation by algae. Limnology and Oceanography, 31, 1081-1093.

Standard methods for examination water and westwater, 1980. American Public Health Association. AWWA, WPCF, Washington DC.

StatSoft Inc., 2010. STATISTICA (data analysis software system), version 9.1. www.statsoft.com.

Taggart C.T. and McQueen D.J., 1981. Hypolimnetic aeration of a small eutrophic kettle lake: Physical and chemical changes. Archive fur Hydrobiologie, 91, 150-180.

Zagan S. and Enache I., 2009. Pollution degree of Tabacarie Lake in 2009. Proceedings of the 3rd International Conference on Environmental and Geological Science and Engineering, 132-136.

Zhang E., Liu E., Jones R., Langdon P., Yang X. and Shen J., 2010. A 150-year record of recent changes in human activity and eutrophication of Lake Wushan from the middle reach of the Yangze River, China. Journal of Limnology, 69, 235-241. 